\title{
ANALISIS KORELASI DAN SPEKTRUM DATA SUARA GENSET UNTUK PEREDAMAN BISING
}

\author{
Sri Arttini Dwi Prasetyowati*, Bustanul Arifin dan Agus Adhi Nugroho \\ Staff pengajar FakultasTeknologi Industri Universitas Islam Sultan Agung \\ Jl. Kaligawe Raya No.KM, RW.4, Terboyo Kulon, Genuk, Kota Semarang 50112 \\ *Email: arttini@unissula.ac.id
}

\begin{abstract}
ABSTRAK
Bising merupakan permasalahan yang seringkali terjadi dan sangat mengganggu apabila tidak diatasi. Penghapusan bising harus didasarkan pada sifat khas sumber bisingnya, yang harus ditemukan sebelum diupayakan peredaman atau penghapusannya. Dalam penelitian ini suara bising dihapus adalah suara genset yang bersifat monoton di laboratorium. Untuk dapat menghapus bising genset terlebih dahulu harus diteliti karakteristik dari sinyal bising tersebut. Adapun yang diteliti adalah korelasi, kroskorelasi, spektrum bising genset yang direkam. Perekaman dilakukan dari jarak berbeda yaitu satu dari tempat sumber dan lainnya dari ruangan yang terganggu kebisingan genset, namun dalam waktu yang sama. Spektrum dicermati dengan menggunakan Fast Fourier Transform.
\end{abstract}

Kata Kunci: korelasi, spektrum, bising genset, fast fourier transform

\section{PENDAHULUAN}

Salah satu penyebab terganggunya konsentrasi manusia adalah polusi suara. Pekerjaan di laboratorium adalah salah satu pekerjaan yang memerlukan konsentrasi penuh. Ruangan yang tenang adalah salah satu fasilitas yang mutlak diperlukan untuk memperoleh hasil peker jaan yang optimal. Secara umum usaha untuk mengurangi polusi suara telah banyak dilakukan, namun belum dapat menghilangkan seluruh polusi suara, dalam arti polusi suara belum dapat dihilangkan seratus persen. Hal ini terutama akibat watak kebisingan yang selalu berubah-ubah dengan cepat.

Bising Genset yang dikategorikan sebagai bising yang monoton biasanya mengandung sifat yang dapat berulang secara periodis atau acak stationer dalam selang waktu cukup panjang. Bunyi-bunyi yang monoton inilah yang terdengar sangat mengganggu, apalagi jika suaranya cukup keras, dan berlangsung bersambungan. Ruang kedap suara tidak dapat digunakan sebagai solusi karena permasalahannya hanya suara Genset saja yang akan diredam, suara selain Genset, seperti percakapan yang ada di dalam ruang, maupun suara alat-alat laboratorium yang lainnya masih harus dapat didengar. Salah satu solusi untuk permasalahan tersebut adalah dengan membuat semacam sistem penghapus bunyi pengganggu dan tetap mempertahankan sinyal-sinyal informasi yang masih diperlukan.

Berikut adalah Gambar posisi perekaman sinyal bising genset yang direkam dengan menggunakan 2 (dua) mikrophon yang sama, dalam satu waktu yang sama, dari sumber bising yang sama, namun mikrophon yang pertama diletakkan di dekat genset (sumber bising) dan mikrophon yang kedua ditempatkan di ruang yang akan diredam bisingnya.

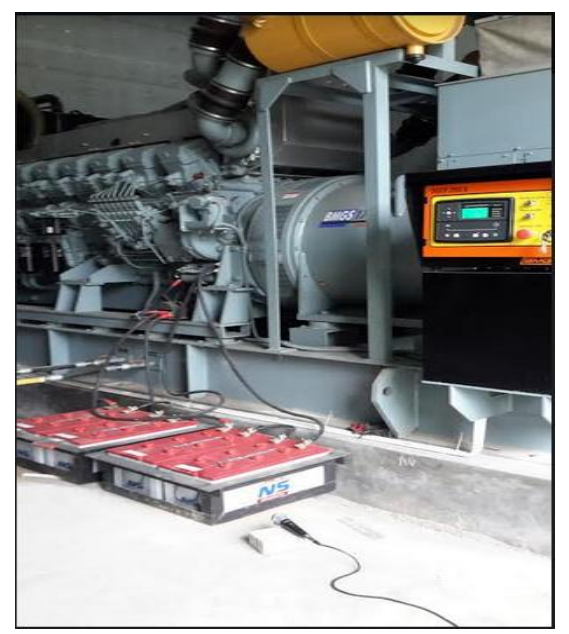

\section{Gambar 1 Sinyal bising Genset direkam dari dekat}

Berdasarkan latar belakang yang telah diuraikan dapat diketahui bahwa untuk membuat alat peredam bising diperlukan analisa mengenai bising itu sendiri. Dalam hal ini bising yang harus dianalisa adalah bising genset. Beberapa analisa yang dilakukan adalah analisa korelasi, analisa spectrum, dan analisa magnitudenya. Korelasi diperlukan dalam penelitian ini, karena dengan analisa korelasi 
akan tampak ada tidaknya korelasi antara bising yang dijadikan referensi dan bising dalam ruang yang akan disunyikan. Juga korelasi antara bising informasi yang tidak boleh ikut terhapus. Analisa spektrum, akan menunjukkan posisi spektrum suara bising genset, baik itu suara genset di sumbernya dan suara genset yang berada dalam ruang yang akan disunyikan. Juga spektrum sinyal informasi yang harapannya tidak berada dalam spectrum yang sama dengan bisingnya.

Selanjutnya dari analisa yang dilakukan, informasi yang dihasilkan digunakan untuk mencari parameter-parameter yan dibutuhkan dalam proses penghapusan bising dengan LMS Adaptif (Haykin, 1996). Tujuan yang akan dicapai dalam penelitian ini adalah menganalisa bising genset, dengan mengamati korelasi dan spektrumnya, dengan menggunakan koefieisn korelasi dan fast fourier transform (FFT).

Faktor penting dalam penelitian penghapus bising adaptif adalah belum adanya alat penghapus bising Ruangan elektronik stand alone, dimana penghapusan dilakukan hanya pada suara yang dikehendaki, namun tetap memepertahankan suara yang merupakan informasi penting yang harus dimunculkan. Selama ini penghapusan bising yang ada hanya menggunakan peredam suara secara fisik dimana semua suara, baik yang diinginkan maupun yang tidak, tetap ikut teredam.

Penelitian ini diawali dengan penelitian tentang korelasi lima sinyal-sinyal bising kendaraan, termasuk statistik dan spektrumnya, pada tahun 2009. Namun dalam penghapusan bising, tidak selalu semua bising dapat terhapus dengan sempurna, apalagi bising tersebut termasuk bising yang acak, pasti tidak akan terhapus dengan sempurna. (Prasetyowati, 2005)

Penelitian selanjutnya diteliti apakah sisa bising yang terjadi sudah tidak menganggu secara signifikan. Cara penelitiannya adalah dengan mengekivalenkan sisa bising yang terjadi, yang dinamakan galat hasil penghapusan bising dengan derau putih Gaussian. (Prasetyowati, 2009).

\section{Korelasi}

Analisa korelasi yang dilakukan pasti tidak lepas dari rumus koefisien korelas. Koefisien Korelasi yang Sederhana adalah Koefisien Korelasi Pearson. Rumus Koefisien korelasi sederhana ini dikemukakan pertama kali oleh
Karl Pearson, seorang ahli Matematika dari Inggris. Koefisien Korelasi antara $\mathrm{x}$ dan $\mathrm{y}$ :

$$
\begin{gathered}
z X_{i}=\frac{\left[X_{i}-\operatorname{mean}(X)\right]}{s . d \cdot(X)} \\
z Y_{i}=\frac{\left[Y_{i}-\operatorname{mean}(Y)\right]}{\text { s.d. }(Y)} \\
r_{X, Y}=\left(\sum_{i=1}^{n}\left[z X_{i} z Y_{i}\right]\right) /(n-1)
\end{gathered}
$$

Dengan n adalah ukuran sampel (Ratner, Bruce, 2009)

Rumus diatas tidak digunakan secara manual dalam penelitian ini, tapi sudah langsung menggunakan perintah yang ada didalam program Matlab. (Prasetyowati, 2005, teknikelektronika.com).

\section{Spektrum dan FFT}

Spektrum sebuah sinyal adalah rentang frekuensi di mana spektrum berada. Keberadaan spektrum suara genset dilihat dari FFT sinyal tersebut. Dalam pnelitian ini digunakan langsung fasilital sptool (Signal Processing Tool) yang ada di Matlab (jayatektronik. wordpress.com)

\section{METODE PENELITIAN}

Setelah ditemukan beberapa hasil studi pendahuluan yang telah dilakukan, penelitian ini melanjutkan tahap-tahap diatas dengan beberapa tahap penelitian berikut:

1. Diteliti karakteristik sinyal bising dengan analisa korelasi, spektrum dan FFT nya.

2. Dicermati nilai korelasi dan grafik korelasinya.

3. Dicermati grafik spektrum dan nilai FFT/ IFFT sinyal bising yang direkan dari dua tempat.

\section{HASIL DAN PEMBAHASAN}

Data yang diambil adalah dua jenis suara. Yang pertama adalah suara genset tanpa suara informasi dan yang kedua adalah suara genset dengan suara informasi.

Berikut Gambar kedua jenis suara tersebut. 


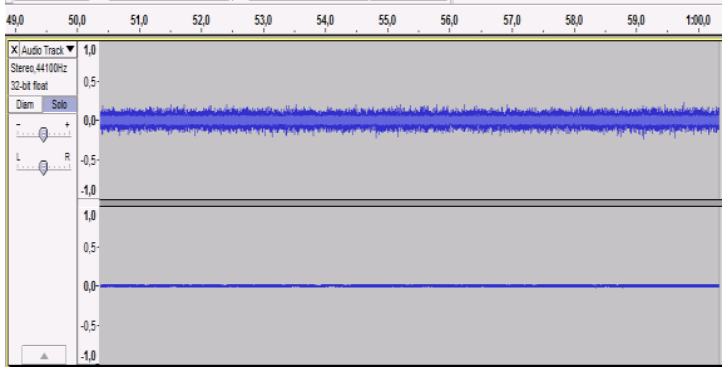

Gambar 2 Suara Genset tanpa suara informasi: di sisi kiri (L) mike diletakkan diluar ruang, di sisi kanan $(R)$ mike diletakkan di dalam ruang.

Gambar 2 belum tampak sinyal tutur di sisi $\mathrm{R}$, sedangkan Gambar 3 sudah memunculkan sinyal tutur disisi R.

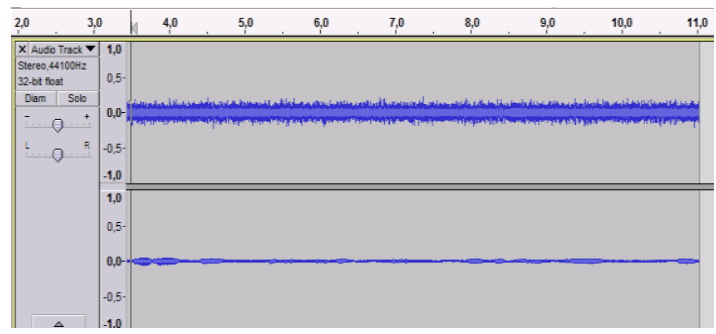

Gambar 3 Suara Genset dengan suara informasi: di sisi kiri (L) mike diletakkan diluar ruang, di sisi kanan $(R)$ mile diletakkan di dalam ruang.

Berikut adalah gambar analisa spektrum dua jenis suara yang direkam.

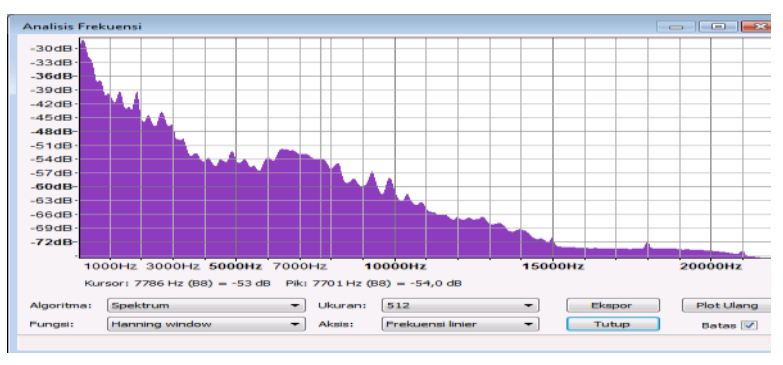

\section{Gambar 4 Analisa Spektrum Suara Generator tanpa suara informasi}

Gambar 4 dan Gambar 5 menunjukkan analisa spektrum suara genset tanpa dan dengan informasi. Kedua gambar menunjukkan bahwa intensitas suara genset baik tanpa informasi maupun dengan informasi berkisar sekitar frekuensi $20 \mathrm{~Hz}$ sd $1000 \mathrm{~Hz}$.

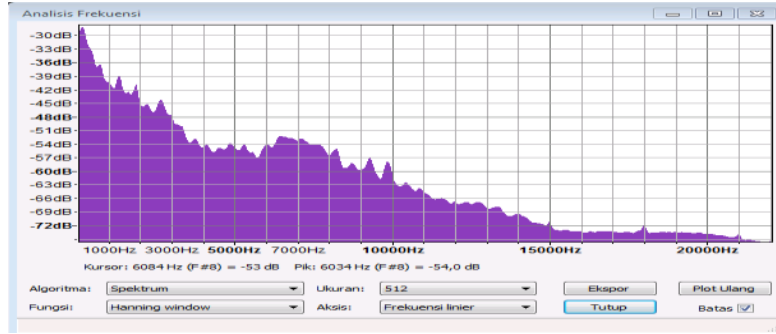

\section{Gambar 5 Analisa Spektrum Suara Generator dengan suara informasi}

Dari hasil analisa spektrum, dapat disimpulkan bahwa untuk menghapus bising suara genset dalam ranah frekuensi masih sulit dilakukan, karena berada dalam frekuensi yang sama

Namun akan dilihat lagi bagaimana sifat korelasi dari sinyal-sinyal suara tersebut.

Analisa korelasi sebelum dilakukan pemrosesan untuk memperkecil delay yang ada antara sinyal bising yang menjadi referensi dan sinyal bising yang masuk dalam ruang yang akan disunyikan tentu sangat kecil. Hasil korelasinya menunjukkan angka $\mathbf{0 , 0 1 5 4}$. Angka yang masih sangat kecil untuk dapat dilakukan penghapusan bising.

Dari hasil diatas, maka untuk penelitian selanjutnya dilakukan proses untuk memperkecil delay yang ada. Gambar 6 dan Gambar 7 adalah sinyal referensi dan sinyal dalam ruang yang akan dihapus bisingnya. Keduanya diambil dari waktu 1000 sampai dengan 1200 detik.

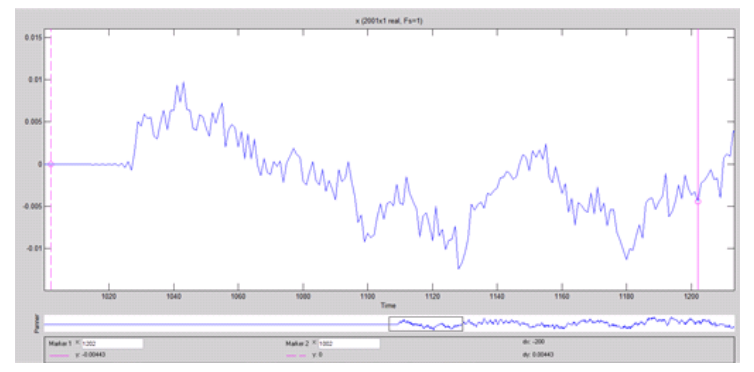

Gambar 6 Sinyal Referensi di perbesar untuk skala waktu 1000 sd 1200 detik 


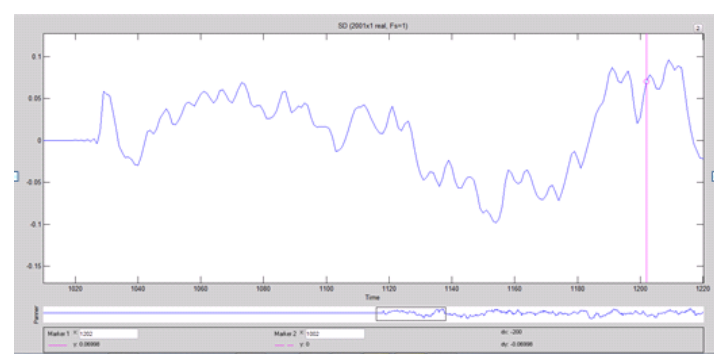

Gambar 7 Sinyal Dalam Ruang di perbesar untuk skala waktu 1000 sd 1200 detik

Proses untuk memperkecil delay dilakukan dengan mencari korelasi dengan pergeseran, dimana sinyal dalam ruang diambil sebagian dan dikorelasikan dengan sebagian sinyal referensi dengan jumlah sampel yang sama, tapi sinyal referensi digeser satu persatu sampai pada sampel ke 1200 , sedang sinyal dalam ruang tetap. Masing-masing dicari korelasinya untuk dicari korelasi tertingginya. Untuk korelasi dengan pergeseran ini akan dibahas dalam penelitian selanjutnya

Hasil FFT akan memunculkan komponan Real dan Imajiner. Hasil FFT dapat digunakan untuk mengukuhkan dapat atau tidak sinyal tersebut dihapus. Sinyal yang jelas dapat terhapus adalah sinyal sinus. Gambar 8 adalah gambar sinyal sinus dengan $\mathrm{k}=1: 0.01: 50.000$ dan $\mathrm{x}=\sin (2 * \pi * \mathrm{k})$.

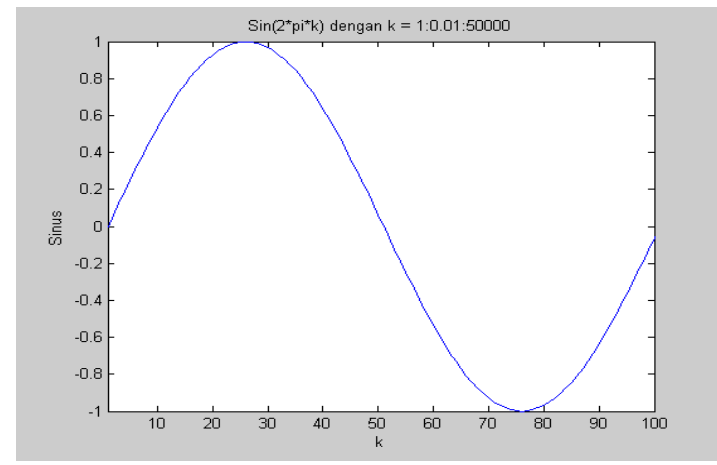

Gambar 8 Fungsi sinus.

Selanjutnya Gambar 9 adalah Gambar FFT fungsi Sinus pada Gambar 8 .

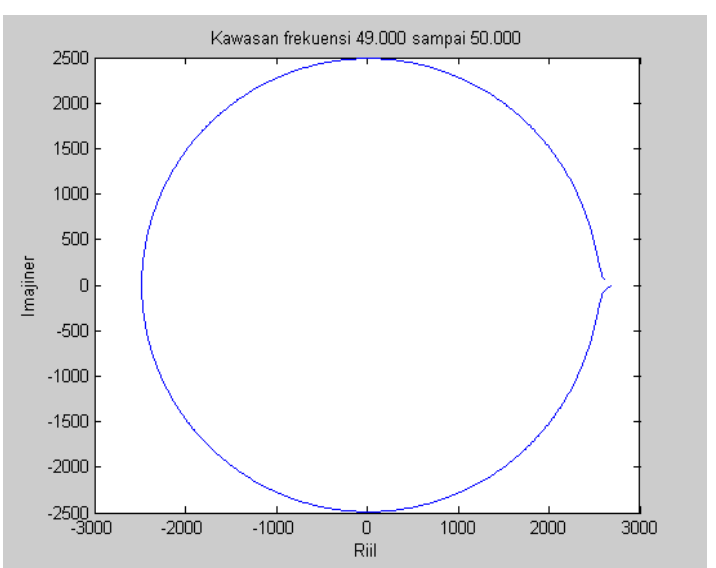

\section{Gambar 9 Nilai FFT fungsi sinus pada frekuensi $49.000-50.000$.}

Terlihat membentuk lingkaran yang sangat sempurna. Bagaimana dengan sinyal dari Genset. Berikut diteliti FFT sinyal Genset pada Gambar 10 dan Gambar 11.

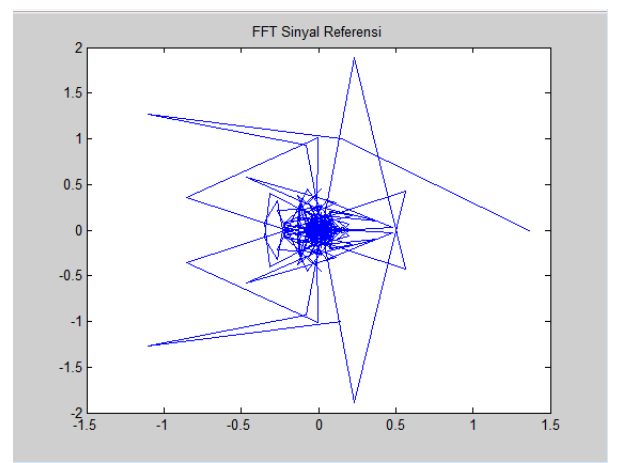

Gambar 10 Nilai FFT fungsi genset sebagai Referensi

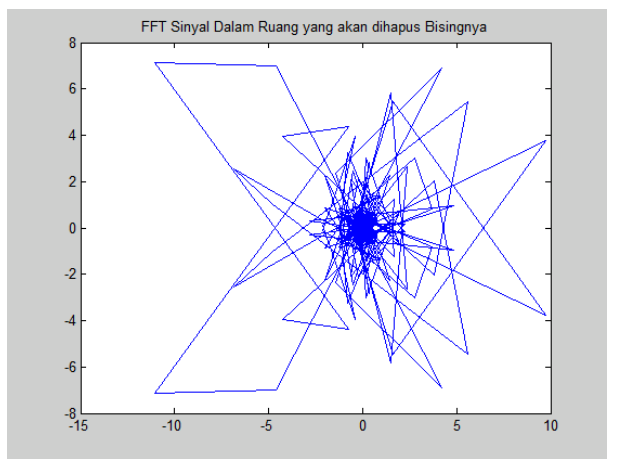

\section{Gambar 11 Nilai FFT genset di ruang yang akan dihapus suara gensetnya}

Sinyal genset tidak membentuk fungsi sinus sempurna juga tidak membentuk lingkaran sempurna. Hal itu disebabkan karena sinyal genset sebenarnya terdiri dari banyak sekali fungsi sinus dengan fase yang berbeda- 
beda. Sudah diketahui bahwa fungsi sinus dapat dihapus dengan sempurna, karena memang sudah memiliki persamaan fungsi terpola. Sinyal genset sangat mungkin terhapus meski tidak sempurna. Keberhasilam penghapusan bising genset ditentukan oleh seberapa besar bising itu sudah dirasa tidak lagi mengganggu.

\section{KESIMPULAN}

Dari penelitian diatas dapat diambil kesimpulan-kesimpulan sebagai berikut:

1. Hasil korelasinya menunjukkan angka 0,0154. Angka yang masih sangat kecil untuk dapat dilakukan penghapusan bising.

2. Kecilnya koefisien korelasi disebabkan karena delay yang ada saat perekaman sinyal genset dari luar dan dari dalam ruang.

3. Menghapus bising suara genset dalam ranah frekuensi masih sulit dilakukan, karena berada dalam frekuensi yang sama.

4. Dari analisa spektrumnya, Sinyal genset terdiri dari banyak sekali sinyal sinus yang memiliki fase yang berbeda-beda. Terlihat dari gambar FFT yang tidak berupa lingkaran penuh seperti FFT sinyal sinus, tapi banyak loncatan-loncatan di luar lingkaran utama. Hal ini mengukuhkan bahwa penghapusan bising dapat dilakukan, namun masih muncul sisa bising yang sudah tidak dapat dihapus lagi.

\section{DAFTAR PUSTAKA}

Haykin, S., (1996), Adaptive Filter Theory, $3^{\text {rd }}$ edition, Prentice Hall.

Prasetyowati. S.A.D., (2005), "Korelasi Antara Dua Sinyal Sama Berbeda Jarak Perekaman Dalam Sistem Adaptif “, Jurnal Trasistor, Vol. 5, No.1, 83-89.

Prasetyowati. S.A.D., Adhi. S., Thomas. S., Jazi. E.I., (2009), "Perbadingan Analisis FFT dan Penghapusan Isyarat Suara Kendaraan Jenis Diesel dan Isyarat Sinus", Forum Teknik, Vol. 32, No. 3.

Prasetyowati. S.A.D., Adhi. S., Thomas. S., Jazi. E.I., (2009), "The Statistics, Correlations, and Spectra of Vehicle's Noise Signals for Adaptive Noise Cancelling", Asian Physics Symposium (APS 2009), Faculty Of Mathematics and Natural Sciences, ITB, Bandung.

https://teknikelektronika.com/pengertiananalisis-korelasi-sederhana-rumus-pearson

https://jayatektronik.wordpress.com/2011/05/03 lbab-3-komunikasi-data
Ratner, Bruce, June (2009)," The correlation coefficient: Its values range between $+1 /-1$, or do they?", Journal of Targeting, Measurement and Analysis for Marketing, Volume 17, Issue 2, pp 139-142 